\title{
Effect of Water Sources on the Radicle Elongation of some Cash Crops from Nigeria
}

\author{
*11OKONWU, K; OGAZIE, CA \\ Department of Plant Science and Biotechnology, University of Port Harcourt, \\ P.M.B. 5323, Port Harcourt, Nigeria \\ *Corresponding author (Email: kalu.okonwu@uniport.edu.ng)
}

\begin{abstract}
Five water sources were used to germinate four different cash crops from Nigeria. The water was sourced from salty water, river water, stream water, rain water and borehole water. The effect of these water sources on the radicle elongation were measured on the seeds of maize (Zea mays L.) variety TZL Comp 4C3DTP2, cowpea (Vigna unguiculata (L) Walp ssp. unguiculata) variety ITO7K-299-6, groundnut (Arachis hypogaea L.) and melon (Citrullus colocynthis (Linn.) Schrad) respectively. The physicochemical properties of the different water used varied from one location to another. The $\mathrm{pH}$ of salty water, river water, rain water and borehole water were alkaline except stream water. $\mathrm{The} \mathrm{Ca}, \mathrm{Mg}$ and total hardness were high in borehole water than other water sources. Salty water had high $\mathrm{Ca}, \mathrm{Mg}, \mathrm{K}$, $\mathrm{Mn}, \mathrm{Fe}, \mathrm{Zn}, \mathrm{Cu}, \mathrm{Cl}, \mathrm{SO}_{4}$ contents when compared with others. The highest radicle growth length after five days were obtained with stream water at $25.36 \pm 7.461 \mathrm{~mm}, 4.47 \pm 1.438 \mathrm{~mm}, 4.75 \pm 1.975 \mathrm{~mm}, 6.24 \pm 1.018 \mathrm{~mm}$ for maize, melon, cowpea and groundnut respectively. There was significant difference $(p>0.05)$ amongst treatments. The seeds of monocotyledon (maize) gave higher radicle length in different water sources when compared to dicotyledonous seeds (melon, cowpea, and groundnut). The study revealed a reduction in radicle growth length with seeds germinated with salty water. (C) JASEM
\end{abstract}

https://dx.doi.org/10.4314/jasem.v21i6.17

Human beings depend on water for domestic, industrial and agricultural purposes. Water is a vital source of human existence since body of man is made up of $70 \%$ water (Park, 2002). Water also plays important role in the life cycle of any given plant. Imbibition of seed is a prerequisite for germination to occur. This process triggers the biochemical components of the seed which were temporarily suspended during quiescent or dormancy. The earth is undergoing rapid environmental changes because of human actions (Vitousek, 1994, Houghton et al., 1995; Pimm et al., 1995; Vitousek et al., 1997; Matson et al., 1997; Tilman, 1999). Humans have greatly impacted the rates of supply of the major nutrients that constrain the productivity, composition, and diversity of terrestrial and aquatic ecosystems. Plants require $\mathrm{N}, \mathrm{P}, \mathrm{K}, \mathrm{Ca}, \mathrm{Mg}, \mathrm{S}$, trace metals, $\mathrm{CO}_{2}$, water, light, and other resources. The mineral element present in water varies from one source to another. Depending on the habitat and species, any one or several of these elements may be limiting to the growth and development of plants. According to Anukam (1997), the main source of water pollution in Nigeria has to do with forestry activities. Deforestation and improper soil tillage practices increase the concentration of soil particles that make their way into water bodies and in turn increases their sediment loads. The discharge of industrial waste materials into bodies of water is another major source of pollution in Nigeria. Discharges from industries such as petroleum, mining, iron and steel, pharmaceuticals, and textiles among others have increased the contents of sulfates and nitrates in water bodies and has altered properties such as color and odor (Adelegan, 2004). These metals and other chemical substance increase the toxicity of water bodies as well as soils. A large percentage of Nigerians derive most of their domestic and drinking water from ponds, stream, and shallow wells. Hence, water pollution is a major health concern that places the health of about 40 million people at risk of diseases such as cholera, dysentery, diarrhea, and typhoid (Anukam, 1997; Adelegan, 2004; Orubu, 2006). On the other hand, water quality is of importance to the agriculturist.

The importance of water to human and other biological systems is enormous, and there are enough scientific and economic facts that, water shortage or its pollution can cause severe decrease in productivity and deaths of living species (Garba et al., 2008; Garba et al., 2010). The United Nations noted a decline in water availability in many regions, and it estimated that global agricultural water consumption will increase by $19 \%$ by 2050 (World Water Day, 2013). Climate change has been shown to affect access to fresh water due to sea level rise, flooding, runoff, and drought. In Nigeria, there is an increase in environmental pollution resulting from anthropogenic activities. Some of these activities that introduce pollutant to the environment include; oil exploration and exploitation, indiscriminate dumping of both solid and liquid waste, waste from abattoirs, organic and inorganic chemicals (Rim-Rukeh et al., 2006; Orubu, 2006; Ekubo and Abowei, 2011; Galadima et al., 2011; Nkereuwem and Udeme, 2015). The water bodies are directly or indirectly affected by several man-made activities. Previous studies have shown that pollution of water bodies adversely affect aquatic life and result in the disruption of the food chain (Ekubo and Abowei, 2011; Galadima et al., 2011).

The study is aimed at analyzing the effect of five different water sources on the germination and radicle elongation of four cash crops namely maize, cowpea, melon and groundnut. 


\section{MATERIALS AND METHODS}

Seeds of maize (Zea mays L.) variety TZL Comp 4C3DTP2 and cowpea (Vigna unguiculata (L) Walp) variety ITO7K-299-6 were obtained from International Institute of Tropical Agriculture (IITA) Ibadan while groundnut (Arachis hypogaea L.) and melon (Citrullus colocynthis (Linn.) Schrad.) were sourced from Choba market, Port Harcourt. The seeds were properly identified by the University of Port Harcourt Herbarium Curator.

Water samples used were collected from River, Stream, Borehole, Salty-water and Rain water following standard procedures. These were collected from Aluu, Buguma and Abuja Park, University of Port Harcourt. The physicochemical analysis of these water samples were determined using standard methods. The $\mathrm{pH}$ meter was used to determine the $\mathrm{pH}$ of these water samples, using buffers 4 and 7 for electrode calibration. Electrical conductivity (E.C) was obtained using conductivity meter, calibrated with ultrapure water. The determination of macro, micro and heavy metals in water were obtained by inductively coupled plasma-optical emission spectrometry (ICP-OES).
The ICP-OES (Perkin-Elmer 8000 model, made in USA) was standardized and calibrated. Before the reading of the water sample(s), deionized water was used to flush out the aspiration tube. The tube was dipped into the water sample(s) and aspirated into the ICP-OES machine by a pneumatic analytical nebulizer and then the values were read straight from the machine screen which also has computer system attached to it. The values were expressed in part per million (ppm). After each sample reading, deionized water was used to clean the tube through which the sample was aspirated. The nitrate, phosphate, sulphate, sulphite and ammonium were determined using Tebnicon 2 auto analyzer (colorimetric method).

Hundred seeds each from the different crops were germinated in sterilized petri dishes and the radical length taken daily for 5-days. The data obtained were subjected to statistical analysis using analysis of variance (ANOVA: two-factor with replication) and the mean separation realized by least significant difference (LSD).

Table 1: Physicochemical of water from different sources and NAFDAC approved limit

\begin{tabular}{lllllll}
\hline Parameter & $\begin{array}{l}\text { Borehole } \\
\text { water }\end{array}$ & $\begin{array}{l}\text { River } \\
\text { water }\end{array}$ & $\begin{array}{l}\text { Rain } \\
\text { water }\end{array}$ & $\begin{array}{l}\text { Stream } \\
\text { water }\end{array}$ & $\begin{array}{l}\text { Salty } \\
\text { water }\end{array}$ & $\begin{array}{l}\text { NAFDAC, } \\
2007\end{array}$ \\
\hline $\mathrm{pH}$ & 8.50 & 8.10 & 9.20 & 7.90 & 9.40 & $6.5-8.5$ \\
$\mathrm{EC}(\mu \mathrm{S})$ & 95.413 & 90.923 & 103.27 & 88.678 & 105.515 & 1000 \\
$\mathrm{Ca}(\mathrm{ppm})$ & 0.720 & 0.686 & 0.779 & 0.669 & 0.796 & -- \\
$\mathrm{Mg}(\mathrm{ppm})$ & 0.198 & 0.188 & 0.214 & 0.184 & 0.219 & 0.20 \\
$\mathrm{~K}(\mathrm{ppm})$ & 0.022 & 0.021 & 0.023 & 0.020 & 0.024 & -- \\
$\mathrm{Na}(\mathrm{ppm})$ & 0.482 & 0.460 & 0.522 & 0.448 & 0.533 & 200 \\
$\mathrm{Ca} \mathrm{Hardness}(\mathrm{mg} / \mathrm{l})$ & 66.567 & 43.313 & 10.697 & 25.261 & 41.112 & 150 \\
$\mathrm{Mg} \mathrm{Hardness}(\mathrm{mg} / \mathrm{l})$ & 38.075 & 30.108 & 11.985 & 21.607 & 36.188 & 150 \\
$\mathrm{Total} \mathrm{Hardness}(\mathrm{mg} / \mathrm{l})$ & 104.642 & 73.421 & 22.682 & 46.869 & 77.299 & 150 \\
$\mathrm{Mn}^{2}(\mathrm{ppm})$ & 0.691 & 0.658 & 0.748 & 0.642 & 0.764 & 0.20 \\
$\mathrm{Fe}^{2+}(\mathrm{ppm})$ & 0.105 & 0.100 & 0.113 & 0.097 & 0.116 & 0.30 \\
$\mathrm{Zn}^{2+}(\mathrm{ppm})$ & 0.687 & 0.655 & 0.744 & 0.639 & 0.760 & 3.00 \\
$\mathrm{Cu}^{+}(\mathrm{ppm})$ & 0.436 & 0.415 & 0.472 & 0.405 & 0.482 & 1.0 \\
$\mathrm{Cl}^{-}(\mathrm{ppm})$ & 0.813 & 0.775 & 0.880 & 0.756 & 0.899 & 250 \\
$\mathrm{SO}_{4}{ }^{2-}(\mathrm{ppm})$ & 0.050 & 0.047 & 0.054 & 0.046 & 0.055 & 100 \\
$\mathrm{NO}_{3}{ }^{-}(\mathrm{ppm})$ & 0.005 & 0.005 & 0.006 & 0.005 & 0.006 & 50 \\
$\mathrm{SO}_{2}(\mathrm{ppm})$ & 0.547 & 0.521 & 0.592 & 0.508 & 0.605 & 0.20 \\
$\mathrm{CO}_{3}{ }^{-}(\mathrm{ppm})$ & 0.189 & 0.180 & 0.205 & 0.176 & 0.209 & -- \\
$\mathrm{NH}_{3}(\mathrm{ppm})$ & 0.009 & 0.008 & 0.010 & 0.008 & 0.010 & -- \\
\hline \multicolumn{5}{c}{ National Agency for Food and Drug Administration and Control (NAFDAC) }
\end{tabular}

Table 2: Radicle growth length of some plants in different water sources

\begin{tabular}{llcccc}
\hline S/N & \multirow{2}{*}{ Water source } & \multicolumn{4}{c}{ Crop radicle length $(\mathbf{m m})$} \\
\cline { 3 - 6 } $\mathbf{1}$ & Rain & Maize & Melon & Cowpea & Groundnut \\
$\mathbf{2}$ & River & $24.76 \pm 6.746^{\mathrm{ab}}$ & $1.21 \pm 0.471^{\mathrm{b}}$ & $3.65 \pm 1.705^{\mathrm{ab}}$ & $4.71 \pm 0.459^{\mathrm{a}}$ \\
$\mathbf{3}$ & Salty & $14.39 \pm 2.211^{\mathrm{b}}$ & $3.06 \pm 0.850^{\mathrm{ab}}$ & $2.48 \pm 0.940^{\mathrm{b}}$ & $4.22 \pm 0.806^{\mathrm{a}}$ \\
$\mathbf{4}$ & Borehole & $23.26 \pm 4.986^{\mathrm{ab}}$ & $3.74 \pm 1.205^{\mathrm{a}}$ & $2.98 \pm 0.807^{\mathrm{ab}}$ & $5.66 \pm 2.604^{\mathrm{a}}$ \\
$\mathbf{5}$ & Stream & $25.36 \pm 7.461^{\mathrm{a}}$ & $4.47 \pm 1.438^{\mathrm{a}}$ & $4.75 \pm 1.975^{\mathrm{a}}$ & $6.24 \pm 1.018^{\mathrm{a}}$ \\
& LSD $_{(0.05)}$ & 10.449 & 1.956 & 2.200 & 2.852 \\
\hline
\end{tabular}

Mean \pm standard deviation; Values followed by the same letter $(s)$ in a column are not significantly different at $P>0.05$ 
Table 3: Two-Factor ANOVA with replication for crops radicle length in different water sources

\begin{tabular}{lrrrrrr}
\hline $\begin{array}{l}\text { Source of } \\
\text { Variation }\end{array}$ & $\boldsymbol{S S}$ & $\boldsymbol{d} \boldsymbol{f}$ & $\boldsymbol{M S}$ & $\boldsymbol{F}$ & $\boldsymbol{P}$-value & $\boldsymbol{F}$ crit \\
\hline Sample & 109.7637 & 4 & 27.44093 & 2.874512 & 0.034915 & 2.605975 \\
Columns & 3657.021 & 3 & 1219.007 & 127.6943 & $1.6 \mathrm{E}-20$ & 2.838745 \\
Interaction & 160.4304 & 12 & 13.3692 & 1.40046 & 0.205991 & 2.003459 \\
Within & 381.8517 & 40 & 9.546292 & & & \\
Total & 4309.067 & 59 & & & & \\
\hline
\end{tabular}

\section{RESULTS AND DISCUSSION}

The physicochemical properties of salt water, rain water, borehole water, stream water and river water revealed a variation in the value of parameters assessed. The $\mathrm{pH}$ of salt water, river water, rain water and borehole water were alkaline except stream water. The $\mathrm{pH}$ range agrees with the report of Daddy et al. (2002). On the other hand, disagrees with the reports by previous scientific studies on different river sources (Edema et al., 2006; Rim-Rukeh et al., 2006; Dhakyanika and Kumara, 2010; Vishwakarma et al., 2013). The $\mathrm{Ca}, \mathrm{Mg}$ and total hardness were high in borehole water than other water sources. Previous reports have shown that the increase in hardness can be attributed to the decrease in water volume in the rate of evaporation at high temperature, high loading organic substances, detergent, chlorides and other pollutant (Rajgopal et al., 2010; Eruola, et al., 2011; Vishwakarma et al., 2013). Salty water had high $\mathrm{Ca}, \mathrm{Mg}, \mathrm{K}, \mathrm{Mn}, \mathrm{Fe}, \mathrm{Zn}, \mathrm{Cu}, \mathrm{Cl}, \mathrm{SO}_{4}$ contents when compared with others (Table I).

The highest radicle growth length after five days were obtained with stream water at $25.36 \pm 7.461$ $\mathrm{mm}, 4.47 \pm 1.438 \mathrm{~mm}, 4.75 \pm 1.975 \mathrm{~mm}, 6.24 \pm$ $1.018 \mathrm{~mm}$ for maize, melon, cowpea and groundnut, respectively (Table II). The analysis of variance showed that there was significant difference $(p>0.05)$ amongst treatments (Table III). The study revealed a reduction in radicle growth length with maize, cowpea and groundnut seeds germinated with salty water when compared to other water sources. The longer the radicle length, the tendency for the roots to absorb nutrients in soil solution. This also provides anchorage for the plant. Both monocotyledon (maize) and dicotyledon (groundnut, cowpea and melon) response to initiation by imbibition for germination to progress to phase II. The radicle length of the cash crops were high when compared with the report of Chukwuka et al (2014), that reported a reduction in the radicle length of maize treated with aqueous extract of $T$. diversifolia and $V$. amygdalina respectively. The osmotic potentials of the different water sources affected the seeds in different ways. This also is a function of the electrical conductivity of the solutions. This agrees with previous reports by Radhouane (2008) and Boureima et al (2011).

Conclusion: The study revealed that the radicle length of seeds germinated with different water sources differs especially with seeds of monocotyledon and dicotyledon. Also, the physicochemical properties of water vary depending on the source. This difference could be a function of the mineral elements inherent in the solution.

\section{REFERENCES:}

Adelegan, MM (2004). Nigerian Petroleum Law and Practice. Fountain Books, Ibadan, Nigeria

Anukam, CL (1997). Water Pollution Control: A Guide to the Use of Water Quality Management Principle. WHO/UNEP

Boureima, S; Eyletters, M; Diouf, M; Diop, TA; Van Damme, P (2011). Sensitivity of seed germination and seedling radicle growth to drought stress in Sesame (Sesamum indicum L.). Research Journal of Environmental Sciences 5(6): 557-564.

Chukwuka, KS; Obiakara, MC; Ogunsumi, IA (2014). Effects of aqueous plant extracts and inorganic fertilizer on the germination, growth and development of maize (Zea mays L.). Journal of Agricultural Sciences, 59(3): 243-254.

Daddy, F; Abubakar, S; Owotunse, S (2002). Effects of different sources of water on water hyacinth growth performance. In: Proceedings of the International Conference on Water Hyacinth, 27 Nov.-01 Dec., 2000, New Bussa, Nigeria, pp. 130-140.

Dhakyanika, K; Kumara, P (2010). Effect of pollution in river Krishni on hand pump water quality. J. Eng. Sci. Technol. Rev. 3(1):14-22.

Edema, MO; Omenu, AM; Fapeta, OM (2006). Microbiology and physiological analysis of different sources of drinking water in Abeokuta. Nigeria Journal Microbiology 13(1): 57-61.

Ekubo, AT; Abowei, JFN (2011). Aspects of Aquatic Pollution in Nigeria. Research Journal of Environmental and Earth Sciences, 3(6): 673693.

Eruola, AO; Ufoegbune, GC; Awomeso, JA; Adeofun, CO; Idowu, OA; Abhulimen, SI (2011). An assessment of the effect of industrial pollution on Ibese River, Lagos, Nigeria. Afr. J. Environ. Sci. Technol. 5(8): 608-615. 
Galadima, A; Garba, ZN; Leke, L; Almustapha, MN; Adam, IK (2011). Domestic Water Pollution among Local Communities in Nigeria-Causes and Consequences. European Journal of Scientific Research, 52(4): 592-603.

Garba, ZN; Gimba, CE; Hamza, SA; Galadima, A (2008). Tetrimetric determination of arsenic in well water from Getso and Kutama, Gwarzo Local Government Area, Kano state, Nigeria ChemClass Journal, 5: 78-80.

Garba, ZN; Hamza, SA; Galadima, A (2010). Arsenic level speciation in fresh water from Karaye Local Government Area, Kano State, Nigeria. International Journal of Chemistry, India. 20(2): 113-117.

Houghton, JT; Meira Filho, LG; Callander, BA; Harris, N; Katterberg, A; Masskell, K (1995). Climate change, 1995 (Eds.). The science of climate change. Contribution of working group I to the second assessment Report of IPCC. Cambridge University Press, Cambridge, UK.

Matson, PA; Parton, WJ; Power, AG; Swift, MJ (1997). Agriculture intensification and ecosystem properties. Science 277: 504-509.

Nkereuwem, SE; Udeme, SU (2015). Oil Pollution and Its Impact on Water Quality in Ibeno Community. Studies in Sociology of Science, 6(2): 8-12.

Orubu, CO (2006). Water Resources, Environment and Sustainable Development in Nigeria. $J$. Hum. Ecol., 19(3): 169-181.

Park, K (2002). Environment and Health In.: Park's Textbook of preventive and social medicine Eds. 17.

Pimm, SL; Rusell, GJ; Gittleman, JL; Brooks, TM (1995). The future of biodiversity. Science, New Series, 269: 347-350.
Radhouane, L (2008). Correlation between germination and adult stage under water stress in some Tunisian autochthonous pearl millet (Pennisetum glaucum (L.)R.Br.). C. R. Biol., 331: 623-630.

Rajgopal, T; Thangamani, A; Sevarkodiyone, SP; Sekar, M; Archunan, G (2010). Zooplankton diversity and physicochemical conditions in three perennial ponds of Virudhunagar district, Tamilnadu. J. Environ. Biol. 31: 265-272.

Rim-Rukeh A; Ikhifa GO; Okokoyo PA (2006). Effects of agricultural activities on the water quality of Orogodo River, Agbor. Nigeria Journal of Applied Sciences Research 2(5): 256259.

Tilman, D (1999). The ecological consequences of changes in biodiversity: A search for general principles. Ecology 80(5): 1455-1474.

Vitousek, PM (1994). Beyond global warming: Ecology and global change. Ecology 75(7): 1861-1876.

Vitousek, PM; Aber, JD; Howarth, RW; Likens, GE; Matson, PA; Schindler, DW; Schlesinger, WH; Tilman, DG (1997). Human alteration of the global nitrogen cycle: Sources and consequences. Ecological Applications 7(3): 737-750.

Vishwakarma, S; Varma, A; Saxena, G (2013). Assessment of water quality of Betwa River, Madhya Pradesh, India. International Journal of Water Resources and Environmental Engineering 5(4): 217-222.

World Water Day (2013). The International year of water cooperation and the thematic consultation on for post-2015 development agenda. Friday 22 March 2013 at The Hague, Netherlands. 